\title{
Effectiveness Evaluation of Zali bet as Reinforcement in Concrete Beam
}

\author{
H.M.A.Mahzuz ${ }^{*}$, M. Ahmed, M. K. Uddin, M. M. Hossain, N. Saquib \\ Department of Civil and Environmental Engineering,Shahjalal University of Science and Technology, Sylhet, Bangladesh \\ *Corresponding Author: mahzuz_211@yahoo.com
}

Copyright (C) 2014 Horizon Research Publishing All rights reserved.

\begin{abstract}
In this paper the yield strength, ultimate strength and modulus of elasticity of a rattan (Calamus guruba, local name in Bangladesh is "Zali bet") were measured. After that the performance of some concrete beams was justified where this rattan was used both as flexural and shear reinforcements. Total eleven beams were tested in this study. Among them seven were singly reinforced beams and were used in flexure test. And the other four beams were prepared for shear test. Concrete properties were kept constant leaving reinforcement the only variable. The lengths were $500 \mathrm{~mm}$ for flexure test and $1025 \mathrm{~mm}$ for shear test having the same width and height. The test results were compared with non-reinforced concrete beams. The results were analyzed using the conventional moment equations and bond stress. Relations between the experimental and theoretical values were made. Finally design of rattan-reinforced beam was also made to understand its contribution physically.
\end{abstract}

Keywords Bond-stress, Deflection, Flexure, Moment Equation, Shear, Zali

\section{Introduction}

Rattans are extensively used for manufacturing furniture and baskets, it accepts paints and stains like wood, and it is available in many colors; it can be worked into many styles. It is a non corrosive material in nature and thermally non-conductive. Rattan is flexible, and is very easy to shape and form. Due to strength and durability it has been used as a construction material in certain areas for centuries, but its application as reinforcement in concrete had received little attention. There are certain limitations to the use of rattan cane; one of them is the starchy interior is attractive to insects. For long lasting structures, it is important to treat these materials against rots and insects. Most importantly, it is important to dry before it is used in construction, rattan cane furniture have been found to have a life span of over 50 years and this will depend on the exposure conditions. In order to design any structural component efficiently, it is necessary to know in advance the strength capability of the material to be used. Rattan presents a problem in this respect since the quality cannot be controlled as it is a naturally available material. All the other materials that are used structurally are manmade and therefore some form of quality control can be exercised during their productions, this has led to some research work on the structural properties of Rattan cane. Lucas and Dahunsi [4] were able to treat rattan cane with some preservatives like creosote and bitumen, while some samples were left untreated. The rattan cane concrete bond strength for untreated samples ranges between 0.1443 and $0.5611 \mathrm{~N} / \mathrm{mm}^{2}$ while samples treated with creosote ranges between 0.0165 and $0.3451 \mathrm{~N} / \mathrm{mm}^{2}$, the bitumen treated samples gave bond strength of between 0.4467 and $0.5729 \mathrm{~N} / \mathrm{mm}^{2}$, depending on the species and natural conditions, as compared to below $3 \mathrm{~N} / \mathrm{mm}^{2}$ obtained for plain-steel concrete bond [9] and above $6 \mathrm{MPa}$ obtained for deformed-steel concrete bond [7,9]. It was also found that the modules of elasticity for three species of Rattan cane were $3396 \mathrm{~N} / \mathrm{mm}^{2}, 516 \mathrm{~N} / \mathrm{mm}^{2}$ and $11106 \mathrm{~N} / \mathrm{mm}^{2}$ for $C$. deerratus, E. macrocarpa and L. secundiflorum respectively $[5]$.

"Zali bet" is one of the two mostly available rattans of Bangladesh. The other one is "Golla bet" (Daemonorops jenkinsiana). Chowdhury [2] studied on the physical and mechanical properties of this rattan. Based on that study another research was conducted by Mahzuz et al [6] focusing on its bond strength with concrete. In that study an experiment was also made to quantify the effectiveness of this rattan as reinforcement in concrete beam. But taking "Zali bet" (Calamus guruba) no study was seen to be conducted. Generally it is very widely used in handicraft sector in Bangladesh which contains a great heritage value. Due to its durability and strength in products it is an encouraging subject for research. Moreover no study was found considering it as reinforcement in concrete beam. Keeping this in mind the bond strength of it with concrete was also tested by Pull-out test. Since Zali bet has smooth surface therefore its tensile strength may not be fully utilized. Therefore three types of specimen of Zali bet were prepared, a) Normal rattan, b) Rattan having ring of GI wire (25 mm pitch) and c) Rattan having spiral of GI wire (25 mm pitch). 
The corresponding result was $0.22,0.46,0.28 \mathrm{MPa}$ respectively. This means Rattan having ring of GI wire (25 $\mathrm{mm}$ pitch) showed the best performance [7]. Using the information got from that research paper an attempt is made in this study to utilize "Zali bet" as reinforcement in a load bearing member like beam. As a preliminary work it is expected that this will provide some initial data for future researchers interested in this field.

\section{Testing Procedure}

The research was performed using the concrete where Ordinary Portland Cement (ASTM Type-1) was used at a mixing ratio of 1:2:3 having the same water-cement $(\mathrm{w} / \mathrm{c})$ ratio (0.5). The fineness modulus (FM) of sand was 2.8 (Table-1). At least three year old rattan-Zali bet (Calamus guruba) was used at the study. The rattan samples were straight and free from any kind of physical fault, such as twist, insect attack, deformation etc.

\subsection{Tension test of Zali:}

In this study Zali samples were tested to find out the yield strength, ultimate strength and modulus of elasticity. Three years old five fault-free straight samples were selected for tension test.

\subsection{Flexure tests}

All the flexure tests were conducted using the same beam size of $500 \mathrm{~mm}$ length (distance between supports was 450 $\mathrm{mm}$ ), $150 \mathrm{~mm}$ width and $150 \mathrm{~mm}$ depth (Figure 1). Clear cover was $12.5 \mathrm{~mm}$ and effective depth was $125 \mathrm{~mm}$. Cross-sectional area of each rattan piece was measured at three different locations (two sides and middle), and then average area was calculated.

All the beams were singly reinforced, that is no reinforcement at top was used. Each beam was reinforced by three $10 \mathrm{~mm}$ bars as shear reinforcement $\left(\mathrm{F}_{\mathrm{y}}=414 \mathrm{MPa}\right)$ at a center to center distance $150 \mathrm{~mm}$. The shear strength of each beam was kept constant at each beam leaving the flexural strength as variable. Due to smooth surface of rattan it might offer low bond strength with concrete. To increase the bond strength Galvanized Iron (GI) wire (1.75 mm diameter) was used in ring form with rattan. The spacing of ring of GI was $25 \mathrm{~mm}$. At the end of ring the GI wire was twisted and extended $12.5 \mathrm{~mm}$. Such formation of GI wire with rattan increased the bond strength with concrete. The reason behind this phenomenon was the twisted and extended portion of GI wire that produced rough surface. And this rough portion offered extra resistance against the pulling force. In such case the bond stress was $0.46 \mathrm{MPa}$, bond stress without GI wire was $0.22 \mathrm{MPa}[6]$.

Table 1. Properties of the concrete used

\begin{tabular}{|c|c|c|c|c|c|c|}
\hline Cement Type & $\begin{array}{c}\text { FM of } \\
\text { Sand }\end{array}$ & $\begin{array}{c}\text { Water } \\
\text { Cement } \\
\text { Ratio }\end{array}$ & $\begin{array}{c}\text { Unit weight } \\
\text { of stone } \\
\left(\mathrm{Kg} / \mathrm{m}^{3}\right)\end{array}$ & Mix ratio & $\begin{array}{c}\text { Compressive } \\
\text { strength } \\
\left(\mathrm{f}_{\mathrm{c}}^{\prime} \mathrm{Mpa}\right)\end{array}$ & $\begin{array}{c}\text { Unit weight } \\
\text { of Concrete } \\
\left(\mathrm{Kg} / \mathrm{m}^{3}\right)\end{array}$ \\
\hline $\begin{array}{c}\text { OPC- } \\
\text { ASTM Type-1 }\end{array}$ & 2.8 & 0.5 & $\begin{array}{c}1500 \pm 100 \\
(19 \mathrm{~mm} \text { downgraded })\end{array}$ & $1: 2: 3$ & $24.5 \pm 3$ & $2357 \pm 200$ \\
\hline
\end{tabular}

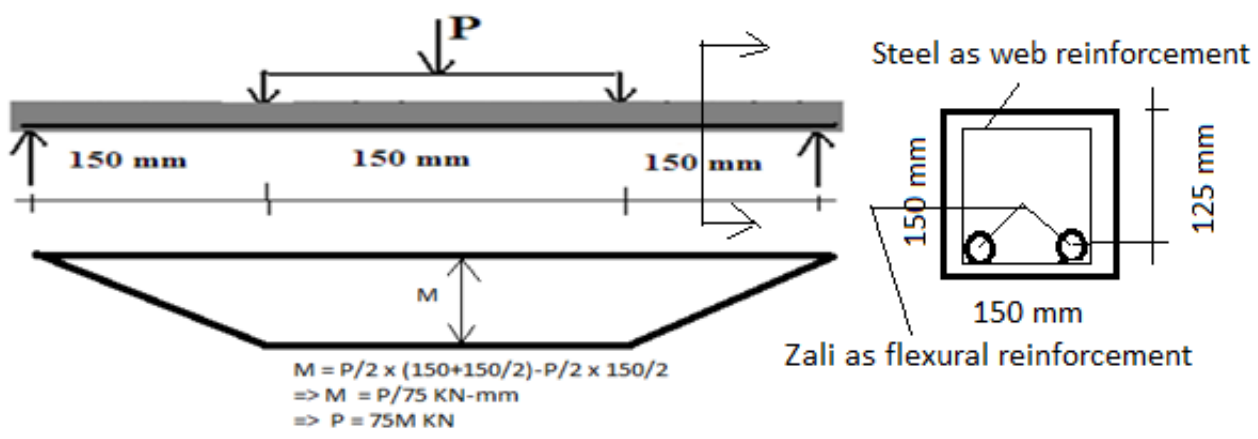

Figure 1. Flexure Test the setup, beam cross-section and bending moment diagram (neglecting the self weight) for beam

A total number of seven beams were prepared out of which:

a) six beams of were prepared with varying percentage of reinforcement $(\rho)$ using rattan (Zali bet) as flexural reinforcement as shown in Figure 2,

b) lastly one beam is prepared using no flexural reinforcement.

Curing was done in a water reservoir for 28 days and each beam was tested using two point loading technique at Universal Testing Machine (UTM). To get the information of deformation, a strain gauge was used at the mid point of the beams during the test of beams. 


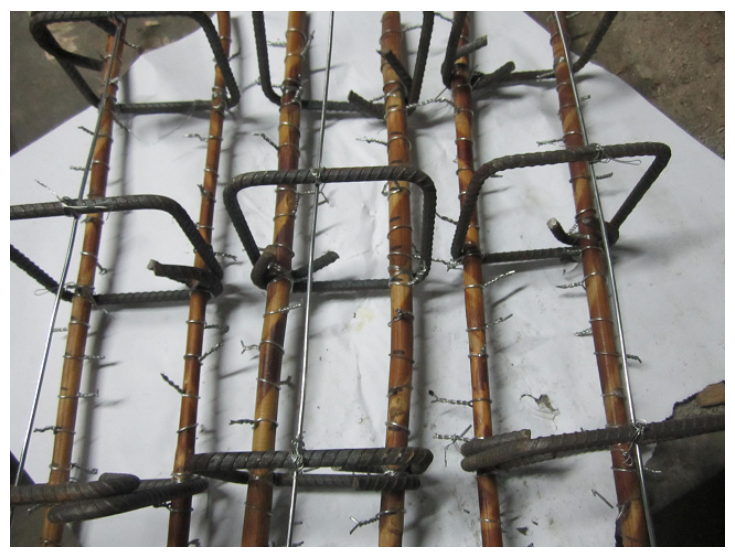

Figure 2. Flexural reinforcement of Beam
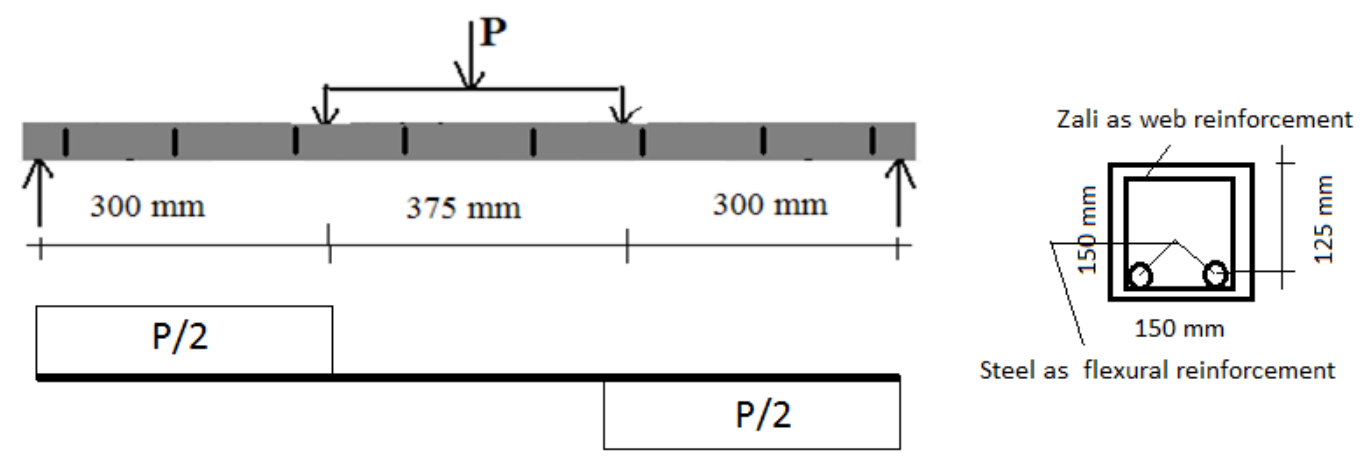

Steel as flexural reinforcement

Figure 3. Setup for beam for Shear Test, beam cross section and shear force diagram (neglecting the self weight) for beam

\subsection{Shear Test of Concrete Beam}

All the shear tests were conducted using a beam size of $1025 \mathrm{~mm}$ length, $150 \mathrm{~mm}$ width and $150 \mathrm{~mm}$ depth (Figure 3). Clear cover was $12.5 \mathrm{~mm}$ and effective depth was $125 \mathrm{~mm}$.

Four beams were prepared for this test, out of which:

a) three beams were prepared where rattan (Zali) was used as shear reinforcement,

b) the rest one was prepared without any shear reinforcement for comparison.

Since this test is related to shear, therefore the flexural capacity of the beams were kept stronger that that of shear capacity. To confirm this situation two $10 \mathrm{~mm}$ dia and two $16 \mathrm{~mm}$ dia rebar (having $\mathrm{f}_{\mathrm{y}}=500 \mathrm{MPa}$ ) were used at top and bottom respectively as flexural reinforcement. All the rattan samples were cut at a length of $125 \mathrm{~mm}$. The spacing of rings rattan were different $(75 \mathrm{~mm}, 100 \mathrm{~mm}$ and $125 \mathrm{~mm})$, but the cross-sectional area was same. The Zali as Shear Reinforcement in concrete beam is shown at Figure 4. The beams were tested at UTM as two points loading system. The specification of the Concrete used was as described at the Sub-heading 2.0.

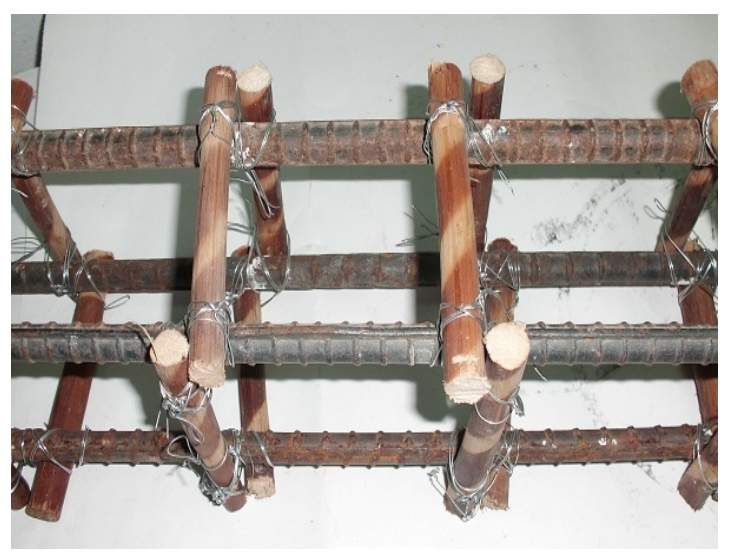

Figure 4. Zali as Shear Reinforcement in concrete beam (full view) 


\section{Experimental Result and Discussion}

\subsection{Results on Tension test of Zali}

Offset method was used to find the yield strength of rattan. Generally the offset value for yield strength of cast iron, wood (parallel to grain) and concrete is $0.02 \%-0.05 \%$, $0.05 \%$ and $0.01 \%-0.02 \%$ respectively [1]. Since no specific offset value was found for rattan therefore the value was taken $0.05 \%$. The yield strength of Zali was found 52 $\mathrm{MPa}$. The stress-strain curves are shown from Figure 5-9. The ultimate strength and modulus of elasticity was $71 \mathrm{MPa}$ and $8805 \mathrm{MPa}$ respectively (Table-2).

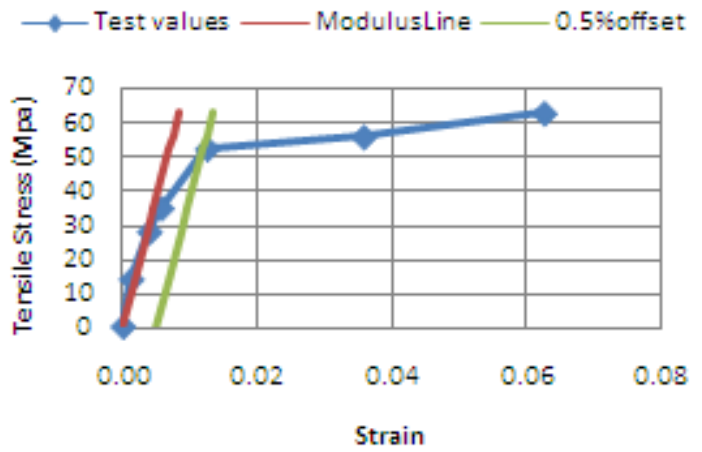

Figure 5. Stress-strain diagram of sample-1

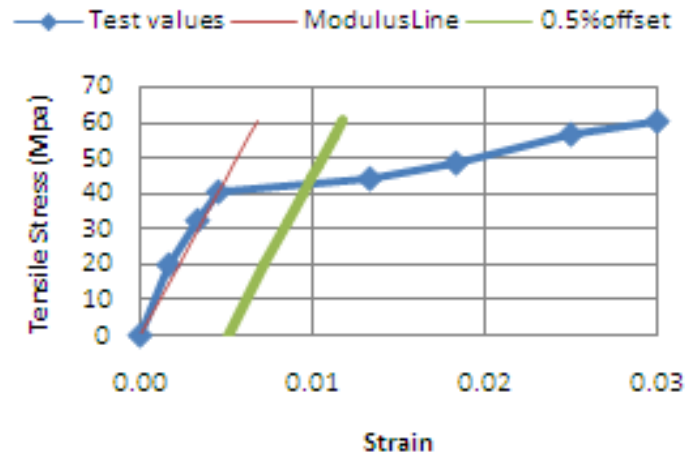

Figure 6. Stress-strain diagram of sample-2

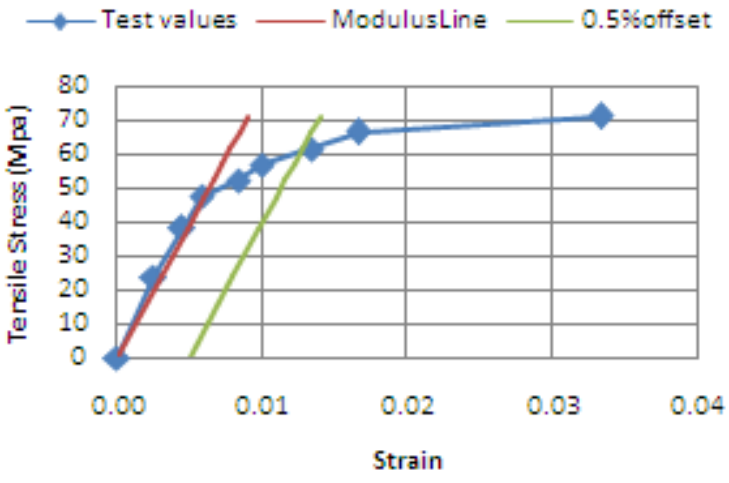

Figure 7. Stress-strain diagram of sample-3

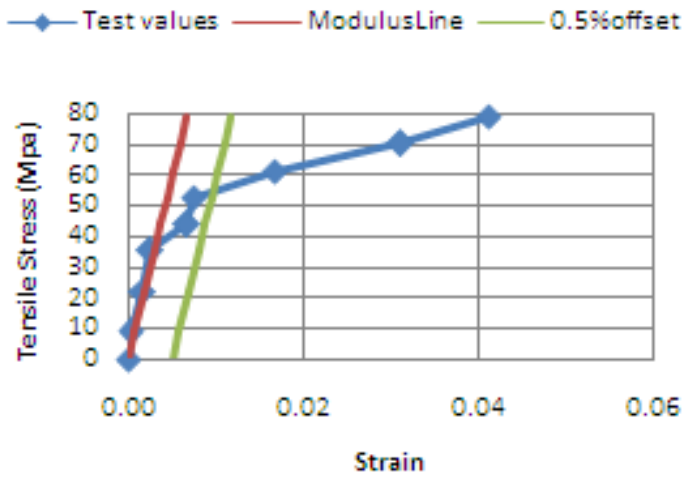

Figure 8. Stress-strain diagram of sample-4

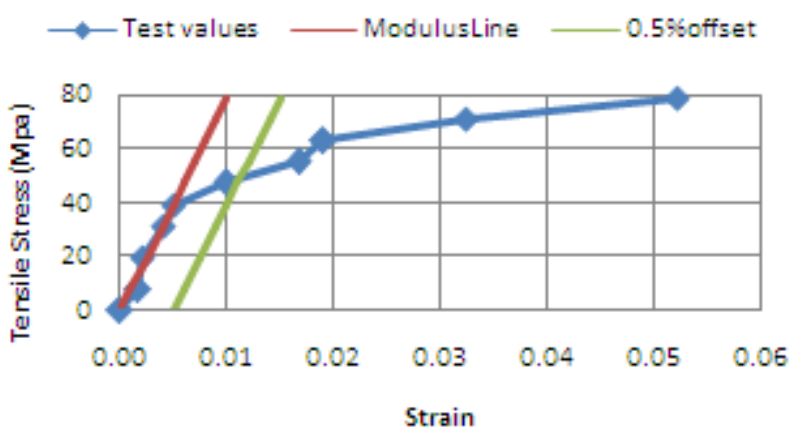

Figure 9. Stress-strain diagram of sample-5

Table 2. Yield Strength Ultimate Strength MoE of rattan (Zali)

\begin{tabular}{|c|c|c|c|c|c|c|c|}
\hline $\begin{array}{l}\text { Sample } \\
\text { No }\end{array}$ & $\begin{array}{c}\text { Yield } \\
\text { Strength } \\
(\mathrm{MPa})\end{array}$ & $\begin{array}{c}\text { Average } \\
\text { Yield } \\
\text { Strength } \\
\left(\mathrm{f}_{\mathrm{Z}}\right) \\
(\mathrm{MPa}) \\
\end{array}$ & $\begin{array}{c}\text { Ultimate } \\
\text { Strength } \\
(\mathrm{MPa})\end{array}$ & $\begin{array}{c}\text { Average } \\
\text { Ultimate } \\
\text { Strength } \\
(\mathrm{MPa})\end{array}$ & $\begin{array}{c}\text { Ratio of Ultimate and Yield } \\
\text { Strength }\end{array}$ & $\begin{array}{l}\mathrm{MoE} \\
(\mathrm{MPa})\end{array}$ & $\begin{array}{c}\text { Average } \\
\operatorname{MoE}\left(\mathrm{E}_{\mathrm{Z}}\right) \\
(\mathrm{MPa})\end{array}$ \\
\hline 1 & 53 & \multirow{5}{*}{52} & 63 & \multirow{5}{*}{71} & \multirow{5}{*}{1.36} & 7486 & \multirow{5}{*}{8805} \\
\hline 2 & 42 & & 61 & & & 9004 & \\
\hline 3 & 60 & & 71 & & & 7925 & \\
\hline 4 & 55 & & 79 & & & 11686 & \\
\hline 5 & 50 & & 79 & & & 7922 & \\
\hline
\end{tabular}




\subsection{Result and Discussion on Flexural Test}

Beams were prepared with various reinforcement ratios $(\rho)$ using rattan at bottom as flexural reinforcement. The test result is shown at Figure 10. It is seen from the figure that as the reinforcement ratio $(\rho)$ was increased the Crushing load $(P)$ was also increased. The information related to crushing load to deflection of beam is presented at Figure 11. From the Load-deflection curves it is seen that continuously more deflection was exhibited by the Zali reinforced beam as the percentage of reinforcement ratio was increased.

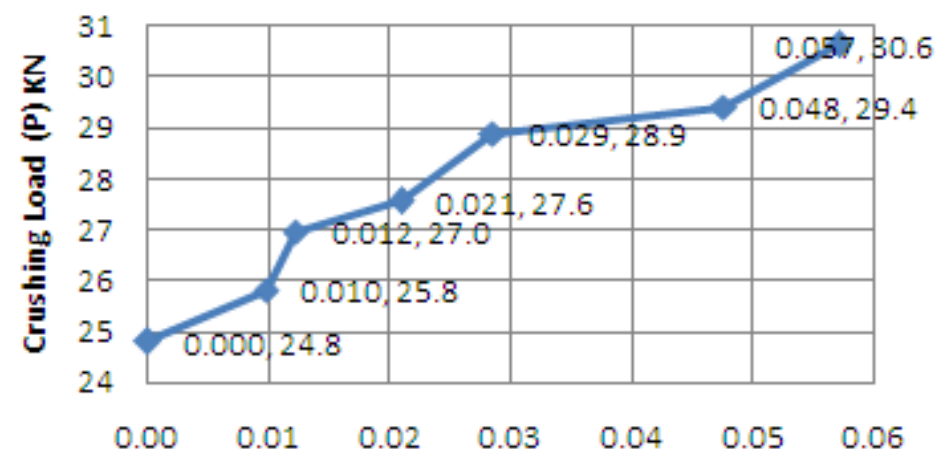

Reinforcement Ratio

Figure 10. Crushing Load at different reinforcement ratio

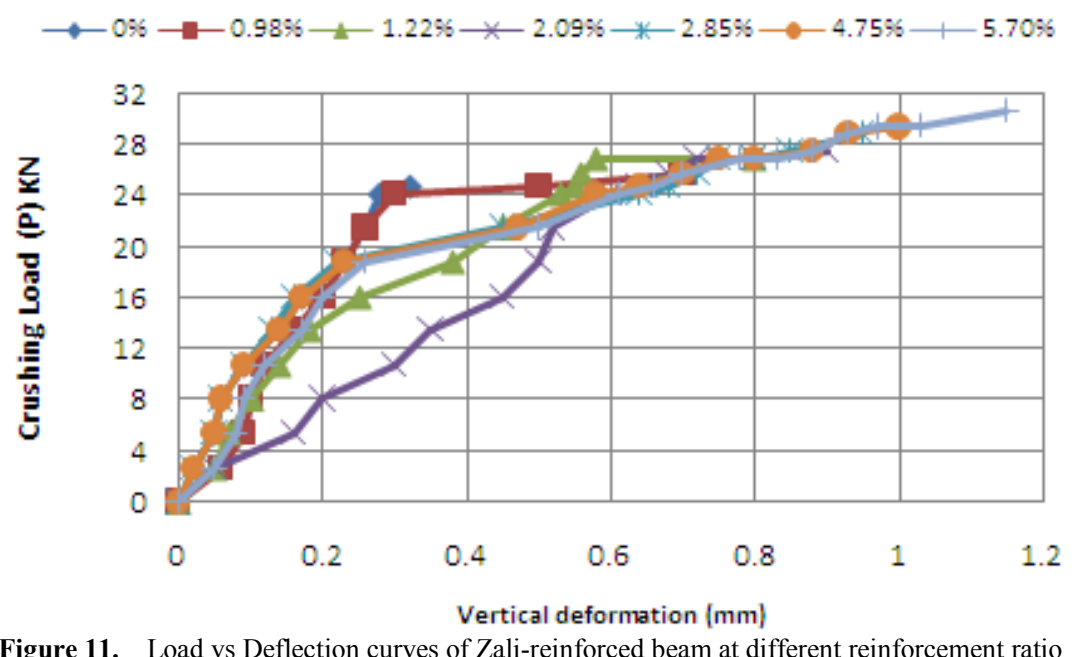

A number of cracks formed during the flexure test. All the cracks were purely flexural in nature. All of them were formed at middle of the beam, started at bottom and propagated vertically toward top. The cracks formed at different loads are of different beams are shown at Table-3.

Table 3. Detailed information on load, crack and deflection

\begin{tabular}{|c|c|c|c|c|c|c|}
\hline Reinforcement Ratio & $\begin{array}{c}\text { Load at } 1^{\text {st }} \\
\text { crack, KN }\end{array}$ & $\begin{array}{c}\text { Load at } 2^{\text {nd }} \\
\text { crack, KN }\end{array}$ & $\begin{array}{c}\text { Ultimate } \\
\text { Load, KN }\end{array}$ & $\begin{array}{c}\text { Maximum crack } \\
\text { width, mm }\end{array}$ & $\begin{array}{c}\text { Ultimate \% } \\
\text { increment of } \\
\text { load }\end{array}$ & $\begin{array}{c}\text { Central } \\
\text { deflection at } \\
\text { Ultimate Load, } \\
\text { mm }\end{array}$ \\
\hline 0.0000 & 24.8 & --- & 24.8 & --- & 0.0 & 0.32 \\
\hline 0.0098 & 24 & --- & 25.8 & 2.25 & 4.0 & 0.7 \\
\hline 0.0122 & 24.5 & --- & 26.96 & 3 & 8.7 & 0.8 \\
\hline 0.0209 & 25 & --- & 27.56 & 2.5 & 11.1 & 0.9 \\
\hline 0.0285 & 25.5 & 27 & 28.88 & 2.5 & 16.4 & 0.95 \\
\hline 0.0475 & 25.5 & 28.5 & 29.4 & 3.25 & 18.5 & 1.0 \\
\hline 0.0570 & 26 & 29.5 & 30.63 & 3.5 & 23.5 & 1.15 \\
\hline
\end{tabular}


It was seen from the test that the non-reinforced concrete beam crushed as $24.8 \mathrm{KN}$ load applied by UTM. Significant increase of load taking ability is shown by the beam where the rattan-Zali was used as flexural reinforcement. It was observed in the test that at the reinforcement ratio 0.0475 , $29.4 \mathrm{KN}$ load was taken by Zali reinforced concrete beam, which is $18.5 \%\left(=\frac{(29.4-24.8) \times 100}{24.8}\right)$ more than that of non-reinforced beam. The central deformation that was detected by strain gauge was $0.32 \mathrm{~mm}$ and $1.0 \mathrm{~mm}$ respectively. Linear shape of the Load-deflection curve was observed as expected for the non-reinforced beam. The beam cracked where the first crack formed. While for Zali reinforced concrete beam the first crack was observed at 25.5 $\mathrm{KN}$. The corresponding central deflection was $0.65 \mathrm{~mm}$ that is much more than non-reinforced beam. After the $1^{\text {st }}$ crack yet the beam was able to take load which indicates the active contribution of Zali. The $2^{\text {nd }}$ (also final) crack was formed at $28.5 \mathrm{KN}$. For all beams load in UTM was measured up to the ultimate capacity.

For steel the equation of balanced ratio is shown in Equation 1 with usual notations. Since, the maximum strain in compression $\epsilon_{u}=0.003$, strain of reinforcement $\epsilon_{\mathrm{Z}}=\mathrm{f}_{\mathrm{Z}} / \mathrm{E}_{\mathrm{Z}}$, $\mathrm{E}_{\mathrm{Z}}=8805 \mathrm{MPa}$, so the modified equation for rattan (Zali) is shown in Equation 2. For rattan considering $\mathrm{f}_{\mathrm{Z}}=52 \mathrm{MPa}$ and $\beta_{1}=0.85$, using Equation 2, balanced reinforcement ratio $\rho_{z}=0.0825$. In this study the maximum reinforcement ratio $\rho$ is 0.057 that is lower than that of $\rho_{\max , z}$. Therefore equations for single reinforced beams are taken to analyze the result. While the minimum reinforcement ratio $\rho_{\min , z}$ is 0.0265 . The detailed calculation is shown below. Based on the above discussion in present study the usable reinforcement ratios are $0.0285,0.0475$ and 0.0570 .

$$
\begin{gathered}
\rho_{z}=0.85 \beta_{1} \frac{f_{c}^{\prime}}{f_{y}} \frac{\epsilon_{u}}{\epsilon_{u}+\epsilon_{z}} \ldots \\
\rho_{z}=0.85 \beta_{1} \frac{f_{c}^{\prime}}{f_{z}} \frac{0.003}{0.003+\frac{f_{z}}{E_{z}}} \\
\rho_{z}=0.85 \beta_{1} \frac{f_{c}^{\prime}}{f_{z}} \frac{26.415}{26.415+f_{z}} \ldots \ldots \\
\rho_{\text {max }, z}=0.75 \rho_{z}=0.75 \times 0.11=0.0825 \\
\rho_{\text {min }, z}=\frac{1.38}{f_{y}}=\frac{1.38}{52}=0.0265
\end{gathered}
$$

Under inelastic analysis considering the beam section cracked the conventional moment equation is Equation [3]. The relation between the load $(\mathrm{P})$ and moment $(\mathrm{M})$ is shown in Equation [4] (Figure 1). Bond stress between concrete and reinforcement will be generated at the contact of them and the amount of bond force will be equal to the multiplication of bond stress and the surface area of reinforcement. A little consideration can expose that Equation [3] can be slightly modified to use the bond force as shown in Equation [5]. Since $A_{z} f_{z}$ (in Equation [3]) is the tension force taken by reinforcement therefore this force can be replaced by bond force. The lever arm of both equations [3] and [5] will be the same.

$$
\begin{aligned}
& M_{\text {theo }}=A_{z} f_{Z}\left(d-\frac{a}{2}\right), \ldots \\
& \text { where } a=\frac{A_{Z} f_{Z}}{0.85 f_{c}^{\prime} b} \\
& P=\frac{M_{\text {exp }}}{75} \ldots
\end{aligned}
$$

(where $\mathrm{P}$ in $\mathrm{KN}$ and $\mathrm{M}_{\exp }$ in $\mathrm{KN}-\mathrm{mm}$ )

$$
\begin{gathered}
M_{\text {theo }}=F\left(d-\frac{a}{2}\right), \\
\text { where } a=\frac{F}{0.85 f_{c}^{\prime} b}
\end{gathered}
$$

Using the equations [3] and [4] the comparison of experimental and thetorical load is presented in Table 4. It seen that the difference between experimental and thetorical load ranges from $35 \%$ to $64 \%$. Similarly, using the equations [4] and [5] the comparison of experimental and thetorical load is presented in Table 5 . In this case that the difference between experimental and thetorical load ranges from $36 \%$ to $-12 \%$. Using flexure equation and bond stress the maximum reinforcement ratio is up to which the experimental values are less than the theoretical values are 0.017 and 0.048 respectively. The equation of bond stress has a closer position with the experimental values than that of equation of flexure (Figure 12). Therefore this is taken to predict the experimental values. The relation between reinforcement ratio $(\rho)$ and $\mathrm{Pt} \mathrm{BS}$ is shown by Equation [6](Figure-12). Also relation between Pt BS and $\mathrm{P}_{\exp }$ is

\begin{tabular}{|c|c|c|c|c|c|c|c|c|c|}
\hline \multirow{2}{*}{ RF Ratio } & \multicolumn{2}{|c|}{ Experimental } & \multicolumn{6}{|c|}{ Theoretical } & \multirow{2}{*}{ Diff P \% } \\
\hline & $\begin{array}{l}\mathrm{P}_{\text {exp }} \\
\mathrm{KN}\end{array}$ & $\begin{array}{c}\mathrm{M}_{\exp } \\
\mathrm{KN}-\mathrm{mm}\end{array}$ & $\begin{array}{c}\mathrm{A}_{\mathrm{z}} \\
\mathrm{mm}^{2}\end{array}$ & $\begin{array}{c}\mathrm{f}_{\mathrm{z}} \\
\mathrm{MPa}\end{array}$ & $\begin{array}{c}\mathrm{D} \\
\mathrm{mm}\end{array}$ & $\begin{array}{c}\mathrm{A} \\
\mathrm{mm}\end{array}$ & $\begin{array}{c}\mathrm{M}_{\text {theo }} \\
\mathrm{KN}-\mathrm{mm}\end{array}$ & $\begin{array}{l}P_{\text {theo }} \\
\mathrm{KN}\end{array}$ & \\
\hline 0.029 & 28.88 & 2166 & 534.38 & 52 & 125 & 8.90 & 3349.84 & 44.66 & -35 \\
\hline 0.048 & 29.4 & 2205 & 890.63 & 52 & 125 & 14.83 & 5445.75 & 72.61 & -60 \\
\hline 0.057 & 30.63 & 2297 & 1068.75 & 52 & 125 & 17.79 & 6452.50 & 86.03 & -64 \\
\hline
\end{tabular}
shown by Equation [7](Figure-13). Since the allowable maximum reinforcement ratio is 0.0825 and the highest reinforcement ratio used in this study was 0.057 therefore prediction of load and moment was also made and presented at Table-6.

$$
\begin{aligned}
& \text { Pt } B S=540.9 \rho+3.52 \ldots \\
& P_{\text {exp }}=0.163 \text { Pt } B S+25.04
\end{aligned}
$$

Table 4. Comparison of experimental and thetorical load considering section cracked 
Table 5. Comparison of experimental and thetorical load using Bond stress

\begin{tabular}{|c|c|c|c|c|c|c|c|c|c|c|c|c|}
\hline $\begin{array}{c}\mathrm{RF} \\
\text { Ratio }\end{array}$ & $\begin{array}{l}\mathbf{P}_{\text {exp }} \\
\mathrm{KN}\end{array}$ & $\begin{array}{l}\text { No } \\
\text { of } \\
\text { bar }\end{array}$ & $\begin{array}{c}\text { Avg } \\
\text { Dia/bar } \\
\text { mm }\end{array}$ & $\begin{array}{l}\text { Length } \\
\mathrm{mm}\end{array}$ & $\begin{array}{c}\text { Total } \\
\text { perimeter } \\
\mathrm{mm}\end{array}$ & $\begin{array}{l}\text { Surf } \\
\text { Area } \\
\mathrm{mm}^{2} \\
\end{array}$ & $\begin{array}{l}\text { BS } \\
\text { Mpa }\end{array}$ & $\begin{array}{c}\mathrm{F} \\
\mathrm{KN}\end{array}$ & $\begin{array}{c}\mathrm{a} \\
\mathrm{mm}\end{array}$ & $\begin{array}{c}\mathrm{M}_{\text {theo }} \\
\mathrm{KN}-\mathrm{mm}\end{array}$ & $\begin{array}{l}\mathrm{P}_{\text {theo }} \\
\mathrm{KN}\end{array}$ & Diff P \% \\
\hline 0.029 & 28.88 & 4 & 13.0 & $150 *$ & 163.85 & 24578 & 0.46 & 11.31 & 3.62 & 1392.75 & 18.57 & 36 \\
\hline 0.048 & 29.4 & 6 & 13.8 & 150 & 259.07 & 38861 & 0.46 & 17.88 & 5.72 & 2183.33 & 29.11 & 1 \\
\hline 0.057 & 30.63 & 7 & 13.9 & 150 & 306.54 & 45980 & 0.46 & 21.15 & 6.77 & 2572.27 & 34.30 & -12 \\
\hline
\end{tabular}

*Note: Length $=150=75+150 / 2$

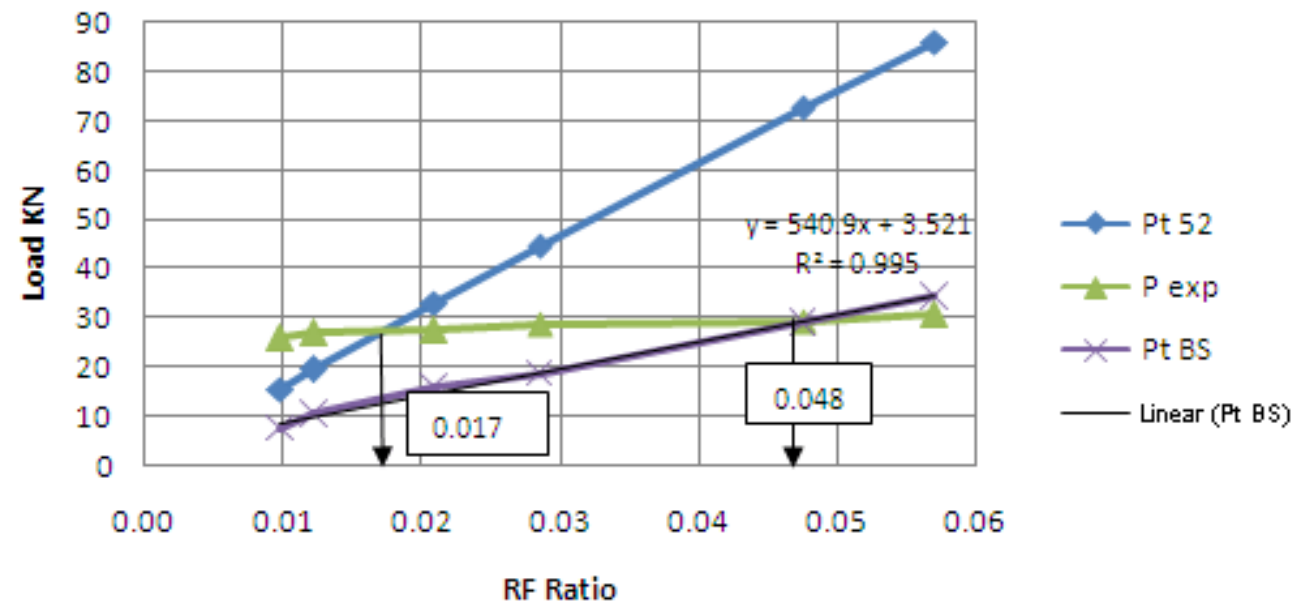

Figure 12. Relative position of $\mathrm{Pe}$ and $\mathrm{Pt}$

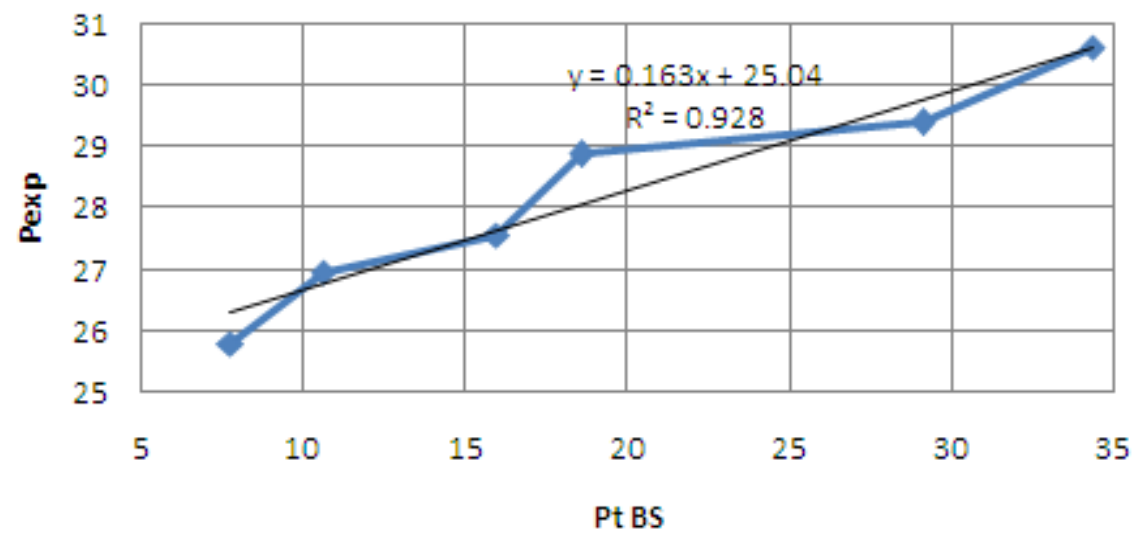

Figure 13. Relation between Pt BS and Pexp

Table 6. Predicted Pt BS, Pexpand Mexp at different reinforcement ratio

\begin{tabular}{|c|c|c|c|}
\hline Reinforcement ratio & $\begin{array}{c}\text { Pt BS } \\
\text { Equ (6) }\end{array}$ & $\begin{array}{c}\mathrm{P}_{\exp } \\
\text { Equ (7) }\end{array}$ & $\begin{array}{c}\mathrm{M}_{\text {exp }}(\mathrm{KN}-\mathrm{mm}) \\
\text { Equ (4) }\end{array}$ \\
\hline 0.06 & 35.98 & 30.90 & 2317.79 \\
\hline 0.07 & 41.38 & 31.79 & 2383.92 \\
\hline 0.08 & 46.79 & 32.67 & 2450.04 \\
\hline $0.0825^{*}$ & 48.15 & 32.89 & 2466.58 \\
\hline
\end{tabular}

*Maximum allowable reinforcement ratio in singly zali-reinforced beam 


\subsection{Result and Discussion Shear Test}

The detailed information and test result about the beams for shear test is shown at Table 7 . No flexural crack was observed in the beams, all the beams were failed showing inclined cracks as assumed. In all tests the load taking capacity of beams were increased as the spacing of the reinforcement was decreased. For example at spacing of $100 \mathrm{~mm}$ the load taking capacity of beam was increased $127 \%$ comparing the non-shear reinforced beam. The experimental results are analyzed by the conventional equation of shear (Equation 8 ) and bond stress. Here bond stress was taken $0.22 \mathrm{MPa}$ since the GI wire was not used in shear reinforcement [7]. The theoretical crushing load using Equation (8) is shown Table 7. While using bond stress the theoretical crushing load is presented in Table 8 . The relative comparison between the experimental and theoretical values are shown in Figure 13. It is seen from Table 7 and 8 that explanation using bond stress has closer position than that of the conventional equation of shear (Equation (7)).

Table 7. The detailed information of shear test result

\begin{tabular}{|c|c|c|c|c|c|}
\hline $\begin{array}{l}\text { Serial } \\
\text { No }\end{array}$ & $\begin{array}{c}\text { Reinforcement } \\
\text { Type }\end{array}$ & $\begin{array}{l}\text { Spacing, } \\
\text { s mm }\end{array}$ & $\begin{array}{c}\text { Cross-sectional area of } \\
\text { Shear Reinforcement } \\
\text { Av } \mathrm{mm}^{2}\end{array}$ & $\begin{array}{c}\text { Crushing } \\
\text { load } \mathrm{P}_{\exp } \\
\mathrm{KN}\end{array}$ & $\begin{array}{c}\% \\
\text { Improvement }\end{array}$ \\
\hline 1 & Rattan-Zali & 75 & $2 * \times 131.25$ & 43.56 & 163 \\
\hline 2 & Rattan-Zali & 100 & $2 \times 131.25$ & 37.63 & 127 \\
\hline 3 & Rattan-Zali & 125 & $2 \times 131.25$ & 35.89 & 117 \\
\hline 4 & No Reinforcement & -- & 0.00 & 16.55 & -- \\
\hline
\end{tabular}

*Note: means two lagged

$$
\begin{gathered}
\mathrm{s}=\frac{\phi \mathrm{A}_{\mathrm{v}} \mathrm{f}_{\mathrm{y}} \mathrm{d}}{\left(\mathrm{V}_{\mathrm{cr}, \mathrm{d}}-\phi \mathrm{V}_{\mathrm{c}}\right)} \\
=>\mathrm{V}_{\mathrm{cr}, \mathrm{d}}=\phi \mathrm{V}_{\mathrm{c}}+\frac{\phi \mathrm{A}_{\mathrm{v}} \mathrm{f}_{\mathrm{y}} \mathrm{d}}{\mathrm{s}}=\frac{\mathrm{P}}{2}
\end{gathered}
$$

Table 8. Theoretical crushing load using Equation (7)

\begin{tabular}{|c|c|c|c|c|c|c|c|c|}
\hline No & $\varphi$ & $V_{c}=0.17 \sqrt{f_{c}^{\prime}} b d$ & $A_{v}$ & $\begin{array}{c}\text { Spacing } \\
\mathrm{S}(\mathrm{mm})\end{array}$ & $\begin{array}{c}\mathrm{V}_{\mathrm{cr}, \mathrm{d}}(=\mathrm{P} / 2) \\
\mathrm{KN}\end{array}$ & $\mathrm{P}$ KN & $\begin{array}{c}\text { \%Diff } \\
\text { of P }\end{array}$ & $\begin{array}{c}\text { Average } \\
\text { Diff\% }\end{array}$ \\
\hline 1 & 0.85 & 15.78 & $2 \times 131.25$ & 75 & 32.73 & 65.5 & 50 & \\
\hline 2 & 0.85 & 15.78 & $2 \times 131.25$ & 100 & 27.89 & 55.8 & 48 & 46 \\
\hline 3 & 0.85 & 15.78 & $2 \times 131.25$ & 125 & 24.99 & 50.0 & 39 & \\
\hline
\end{tabular}

\begin{tabular}{|c|c|c|c|c|c|c|c|c|c|}
\hline $\begin{array}{l}\text { Bond stress } \\
\text { Mpa }\end{array}$ & $\mathrm{v}_{\mathrm{c}}^{\prime}=0.17 \sqrt{f_{c}^{\prime}}$ & $\mathrm{V}_{c}^{\prime} \mathrm{Kip}$ & Dia & $\begin{array}{l}\text { No of } \\
\text { bar }\end{array}$ & $\begin{array}{l}\text { Force } \\
\text { /bar }\end{array}$ & $\begin{array}{c}\text { Total } \\
\text { (2 lagged) }\end{array}$ & $\begin{array}{l}\text { Pt BS } \\
\text { KN }\end{array}$ & Diff P \% & Average Diff $\%$ \\
\hline 0.22 & 0.84 & 15.78 & 12.9 & 4 & 1.11 & 8.91 & 24.7 & -43 & \multirow{3}{*}{-42} \\
\hline 0.22 & 0.84 & 15.78 & 12.9 & 3 & 1.11 & 6.68 & 22.5 & -40 & \\
\hline 0.22 & 0.84 & 15.78 & 12.9 & 2 & 1.11 & 4.46 & 20.2 & -44 & \\
\hline
\end{tabular}

Table 9. Theoretical crushing load using bond stress 


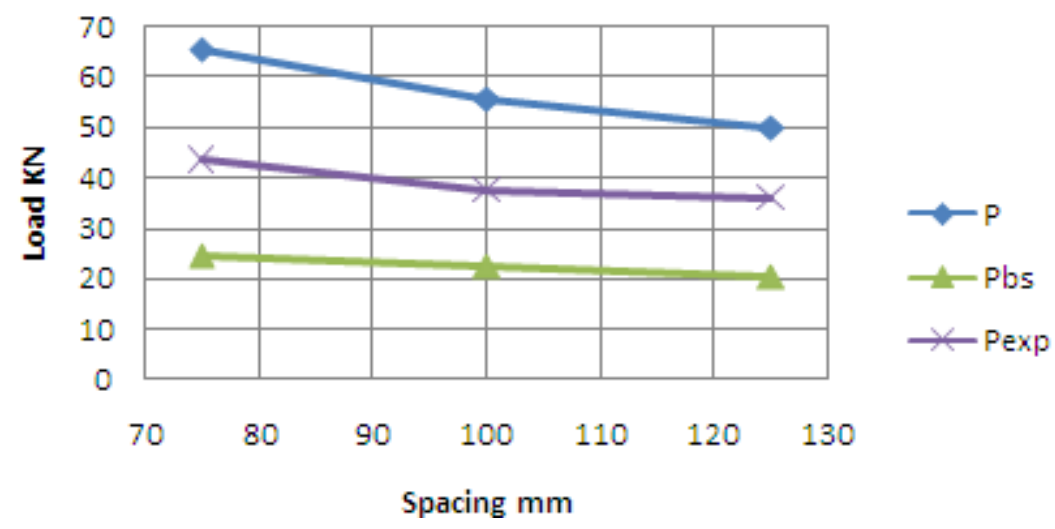

Figure 14. Ultimate load Vs spacing of shear reinforcement

\subsection{Design Example}

Studies were done by Dutta and Rose [3] and Uddin et al [10] using bamboo (local name Borak, and scientific name Bambosa balcoa) and rattan (local name Golla, and scientific name Demonorops jenkinsina) as reinforcement in concrete beam having the same experimental setup described in this paper. The yield strengths were 90 and $52 \mathrm{MPa}$ respectively. The result regarding ultimate load against reinforcement ratio is shown in Table [10] and [11]. It is seen from the comparison that bamboo and golla reinforced beams have higher load taking ability than that of Zali-reinforced beam. And though the yield strengths of Golla and Zali are same yet the effectiveness of Golla was higher in beams as reinforcement.

Table 10. Ultimate load at different reinforcement (bamboo) ratio

\begin{tabular}{|c|c|}
\hline $\begin{array}{c}\rho \\
\text { in Beam }\end{array}$ & $\begin{array}{c}\text { Ultimate } \\
\text { Load, KN }\end{array}$ \\
\hline 0.009 & 24.73 \\
\hline 0.011 & 35.48 \\
\hline 0.016 & 41.93 \\
\hline 0.020 & 45.69 \\
\hline 0.024 & 48.38 \\
\hline 0.030 & 52.68 \\
\hline 0.036 & 60.20 \\
\hline
\end{tabular}

Table 11. Ultimate load at different reinforcement (Golla) ratio

\begin{tabular}{|c|c|}
\hline $\begin{array}{c}\rho \\
\text { in Beam }\end{array}$ & $\begin{array}{c}\text { Ultimate } \\
\text { Load, KN }\end{array}$ \\
\hline 0.0122 & 25.5 \\
\hline 0.0195 & 28.6 \\
\hline 0.02 .83 & 29.3 \\
\hline 0.0320 & 32.3 \\
\hline 0.0444 & 38.0 \\
\hline 0.0556 & 41.3 \\
\hline
\end{tabular}

Considering flexural capacity to visualize the effect of the above discussion a design is made to know the dimension ( $\mathrm{L}$ in meter) of a square shaped room. Let a slab (75 mm thick) supported by four singly zali-reinforced simple supported single span beams. Also consider two live loads (LL) $2.0 \mathrm{KN} / \mathrm{m}^{2}$ and 0.0 concrete unit weight 23 $\mathrm{KN} / \mathrm{m}^{3}$. The total loads in Ultimate Strength Design (USD) are, $1.2 \times\left(\frac{75}{1000} \times L^{2} \times 23\right)+1.6 \times\left(2 \times L^{2}\right)=5.27 L^{2} K N$ and $1.2 \times\left(\frac{75}{1000} \times L^{2} \times 23\right)=2.07 L^{2} K N$. Therefore each beam takes $w 1=\frac{5.27 L^{2}}{4 L}=1.3175 L \quad \mathrm{KN} / \mathrm{m}$ and $w 2=$ $\frac{2.07 L^{2}}{4 L}=0.5175 L \mathrm{KN} / \mathrm{m}$. Therefore the moment is shown by Equation (10). The detailed result is put on Table 12 where the experimental moment is taken from Table 4 and Table 6. After that the span (L) was calculated using Equation (10). Obviously in such case the cross-section of beam was considered same as shown by Figure 1 .

$$
M=\left\{\begin{array}{c}
\frac{w_{1} l^{2}}{8}=\frac{1.3175 L^{3}}{8} \\
\frac{w_{2} l^{2}}{8}=\frac{0.5175 L^{3}}{8}
\end{array}\right\}
$$

Table 12. Variation of span (L) with respect to Moment (flexural design)

\begin{tabular}{|c|c|c|c|}
\hline \multirow{2}{*}{ RF Ratio } & \multirow{2}{*}{$\begin{array}{l}\text { Moment } \\
\text { KN-m }\end{array}$} & \multicolumn{2}{|c|}{ Span, L (m) } \\
\hline & & $\mathrm{LL}=2 \mathrm{KN} / \mathrm{m}^{2}$ & No LL \\
\hline 0.029 & 2.166 & 2.36 & 3.22 \\
\hline 0.048 & 2.205 & 2.37 & 3.24 \\
\hline 0.057 & 2.297 & 2.41 & 3.29 \\
\hline 0.06 & 2.318 & 2.41 & 3.30 \\
\hline 0.07 & 2.384 & 2.44 & 3.33 \\
\hline 0.08 & 2.450 & 2.46 & 3.36 \\
\hline 0.0825 & 2.467 & 2.47 & 3.37 \\
\hline
\end{tabular}

Considering shear capacity another attempt can be made to visualize the capacity of rattan as shear reinforcement. Considering the above mentioned loading and geometric condition the equation of shear for is shown in Equation (11). The detailed result is put on Table 13 where the values of crushing load were taken from Table 7 and after that the span (L) was calculated using Equation (12). Obviously in such case the cross-section of beam is same as shown by Figure 3. 


$$
\begin{aligned}
& V=\left\{\begin{array}{l}
\frac{w_{1} l}{2}=\frac{1.3175 L^{2}}{2} \\
\frac{w_{2} l}{2}=\frac{0.5175 L^{2}}{2}
\end{array}\right\} \\
& P=\left\{\begin{array}{l}
2 V=1.3175 L^{2} \\
2 V=0.5175 L^{2}
\end{array}\right\}
\end{aligned}
$$

Table 13. Variation of span (L) with respect to crushing load (shear design)

\begin{tabular}{|c|c|c|c|c|}
\hline \multirow{2}{*}{ Serial No } & \multirow{2}{*}{$\begin{array}{c}\text { Spacing, } \\
\text { s mm }\end{array}$} & \multirow{2}{*}{$\begin{array}{c}\text { Crushing load } \\
\mathrm{P}(=2 \mathrm{~V}) \mathrm{KN}\end{array}$} & \multicolumn{2}{|c|}{ Span, L (m) } \\
\cline { 3 - 5 } & 75 & 43.56 & 5.75 & 9.17 \\
\hline 1 & 100 & 37.63 & 5.34 & 8.53 \\
\hline 2 & 125 & 35.89 & 5.22 & 8.33 \\
\hline 3 & No shear reinforcement & 16.55 & 3.54 & 5.66 \\
\hline 4
\end{tabular}

\section{Conclusion}

In this study evaluation was made on the use of a naturally available material- rattan (Zali) as both flexural and shear reinforcement in concrete beams. To understand the comparative scenario, beams having no reinforcement were also prepared. As a result it was seen that, the load taking capacity was upgraded by the use of rattan as reinforcement comparing to the non-reinforced beams. Since very few research was seen focusing on rattan as possible reinforcement in concrete, therefore the result of this research can provide the preliminary baseline for more research in this field.

The main concluding points of the study are:

a. Continuous increment of load taking ability was observed as the reinforcement ratio was increased in Flexure test. According to the test results the maximum $23.5 \%$ more load was taken by beams reinforced by rattan (Zali) comparing to non-reinforced beam (at a reinforcement ratio 0.057).

b. Continuous increment of load taking ability was observed as the spacing of reinforcement was decreased in Shear test. According to the test results the maximum $163 \%$ more load was taken by beams reinforced by rattan (Zali) comparing to non-reinforced beam.

c. The maximum and minimum reinforcement ratio was 0.0265 and 0.0825 respectively. In present study the maximum reinforcement ratio was 0.0570 . Even at this ratio the placing of flexural reinforcement became too difficult to organize maintaining the same effective depth.

d. The result considering bond stress entailed closer position with the experimental results of flexure test than that of the conventional moment equation. Considering bond stress in analysis, 0.048 is the maximum reinforcement safe ratio up to which the thetorical values lies below the experimental value. After that though relations are made between
Pt BS, $\rho$ and $P_{\text {exp }}$ (in Equation (6) and (7)) yet the experimental results will be less than the theoretical values.

e. The result considering bond stress entailed lower position $(42 \%)$ with the experimental results of shear test. The result considering shear equation entailed higher position (46\%) with the experimental results of shear test.

f. The longevity of Zali as reinforcement was not studied in this paper. But for low load bearing and non important structures such reinforcement may be an effective alternative. Design made at section 3.4 showed the possible dimensions of a single story square shaped room with slab supported by the beams reinforced by rattan (Zali) considering two types of live load. The results showed that for small rooms such reinforcement may be used as an alternative of conventional reinforcement.

\section{Acknowledgements}

Humble acknowledgement of gratefulness is expressed to

a) The Ministry of Science and Technology, Peoples' Republic of Bangladesh for providing the financial help through the NST Fellowship (2012-13).

b) The Department of Civil and Environmental Engineering, Shahjalal University of Science \& Technology, Sylhet, Bangladesh for providing all the necessary laboratory supports.

c) The Seven Rings Cement Ltd. for providing the OPC needed for the test.

\section{REFERENCES}

[1] Ahmed I, "Theory and Practice of Testing the Strength of Materials", 1995: 23. 
[2] Chowdhury MQ. Assessment of some physical and mechanical properties of Golla bet (Daemonorops jenkinsiana) from north-eastern region of Bangladesh, Journal of Bamboo and Rattan, 2004; 3(3): 195-201, also available online - www.vsppub.com

[3] Dutta J, Rose RH. Application of Bamboo as Flexural \& Shear Reinforcement in Concrete Beam, an Undergraduate Thesis, Department of Civil \& Environmental Engineering of Shahjalal University of Science \& Technology, 2013; 42.

[4] Lucas EB, Dahunsi BIO. Bond strength in Concrete of canes from three rattan species, Journal of Applied Science, Engineering and Technology, 2004; 4(1): 1-5.

[5] Lucas EB, Dahunsi BIO. Characteristics of three western Nigerian rattan species in relation to their utilization as construction materials, Journal of bamboo and Rattan. 2004; $3(1) ; 45-56$.

[6] Mahzuz HMA, Ahmed M, Uddin MK, Hossain MM, Saquib N. Identification of Some Properties of a Rattan (Daemonorops jenkinsiana), accepted for publication at the
International Journal of Sustainable Materials and Structural Systems, Inderscience Publishers, 2013; 03.

[7] Mahzuz HMA, Ahmed M, Uddin MK, Hossain MM, Saquib N. Determination of Tensile Stress and Bond Stress with Concrete of a Rattan (Calamus guruba), Scholars Journal of Engineering and Technology (SJET), 2013; 1(1):39-43.

[8] Mahzuz HM A, Ahmed M, Dutta J, Rose RH. Determination of Several Properties of a Bamboo of Bangladesh, Journal of Civil Engineering Research, 2013; 3(1):16-21, DOI: 10.5923/j.jce.20130301.02.

[9] Pul S. Loss of Concrete-Steel Bond Strength under Monotonic and Cyclic Loading of Lightweight and Ordinary Concretes, Iranian Journal of Science \& Technology, Transaction B: Engineering, 2010; 34(B4):397-406.

[10] Uddin MK, Hossain MM, Saquib N. Use of Rattan as Reinforcement in Concrete Beam, An undergraduate thesis, Department of Civil \& Environmental Engineering of Shahjalal University of Science \& Technology, Sylhet,2013; 21. 